\title{
EFFECTS OF TWO NATURAL DIETS ON THE RESPONSE OF THE PREDATOR ARMA CHINENSIS (HEMIPTERA: PENTATOMIDAE: ASOPINAE) TO COLD STORAGE
}

\author{
LI, X. P. ${ }^{1,2}-$ SONG, L. W. ${ }^{2}-$ Coudron, T. A. ${ }^{3}-$ ZUO, T. T. ${ }^{2}-$ CHEN, Y. Q. ${ }^{2}-$ ZHANG, $^{2}{ }^{2}-$ \\ WU, S. A. ${ }^{*}$
}

${ }^{1}$ Key Laboratory for Silviculture and Conservation of Ministry of Education, Beijing Forestry University, Beijing, China

${ }^{2}$ Jilin Provincial Academy of Forestry Sciences, Changchun 130033, China

${ }^{3}$ Biological Control of Insects Research Laboratory, USDA Agricultural Research Service, Columbia, Missouri 65203, USA

*Corresponding author

e-mail: lxpjsx@126.com; sananwu@bjfu.edu.cn; phone: +86-010-6233-7731

(Received $10^{\text {th }}$ Jul 2019; accepted $15^{\text {th }}$ Nov 2019)

\begin{abstract}
The preservation and rearing of insect natural enemies is the key for biological control. The biological (survival, longevity and the fecundity) and biochemical (low-molecular-weight carbohydrates, glycerol and fatty acids contents) indexes of Arma chinensis fed by Antherea pernyi (diet AP) or Tenebrio molitor (diet TM) were measured after cold storage treatments. The results showed that the diet affected several biological and biochemical parameters, but varied with the length of cold storage. The survival rate and longevity after 30-day cold storage, and the fecundity after 40-day cold storage were significantly higher for adults reared on TM compared to AP. The super-cooling points and the freezing points were significantly lower for adults reared on TM than AP. Low-molecular-weight carbohydrates, glycerol and unsaturated fatty acids were significantly higher for TM than for AP. The structural equation model showed that diet influenced survival, fertility and SCPs of A. chinensis indirectly through the enzyme activity, and the content of carbohydrates, glycerol and unsaturated fatty acids. These results suggested that the nutrient content of diets affects the accumulation of cold-resistant substances, metabolism level and activities of related enzymes in A. chinensis in a manner that enhances tolerance to cold storage.
\end{abstract}

Keywords: natural enemies, cold tolerance, rearing, development, low-molecular-weight carbohydrates, fatty acids

\section{Introduction}

The preservation and transportation of living insects and the rearing of these insects in sufficient numbers and quality for fluctuating markets is one of the obstacles to the use of insect natural enemies for biological control (Coudron et al., 2007). According to the principle of insect cryogenics, cold storage (cryopreservation technology) may be a useful technique to store and ship insects for extended periods, and accumulate sufficient numbers of insects for the undulating and unpredictable demands, and provide the protection of some endangered insect species (Coudron et al., 2007; Leopold, 2007). Cold storage tolerance in insects has significant plasticity (Gotthard and Nylin, 1995), which can be affected by multiple endogenous and exogenous factors. The effect of temperature, photoperiod, age/stadium on the cold tolerance of insects have been researched extensively (Hodkova and Socha, 1995), whereas the effects of the nutrient quality (diet) are less known (Tzanakakis et al., 1992; Ruberson et al., 1998). Previous studies showed that cold storage tolerance of predators improved by selecting 
appropriate developmental stages, temperatures and feeding parameters (Coudron et al., 2007). For example, the survival rate and the reproductive rate of Podisus Maculiventris and Chrysopa Carnea enhanced by the nutrient quality of diets after the cold storage and pre-processed in cold storage (Chang et al., 1995; Thorpe and Aldrich, 2004). The low temperature survival of Nasonia vitripennis significantly improved when parasitism occurred in a host that of those contained more cryoprotectants (glycerol and alanine) (Rivers et al., 2000). The cold storage capacity of Cotesia marginiventris adults enhanced with feeding honey or sucrose (Ergin and Uckan, 2003). Egg viability of the $P$. maculiventris adults fed artificial diets was significantly higher than that fed by natural prey (Coudron et al., 2009), which may result from the high protein content and low lipid content contained in the artificial diets (Coudron et al., 2007). Those studies focused on the effect of diet on growth and fecundity indexes after cold storage. However, we know less about how diet influences biochemical indexes of insects after cold storage. Consequently, the physiological mechanisms linking dietary nutrition and cold storage tolerance of a predatory insect are still not known.

Arma chinensis is a predatory insect that is widely distributed in more than 10 provinces in northern China. They prey on several lepidopteran, coleopteran and hemipteran insect pests of agricultural and forestry ecosystems (Chai et al., 2000; Chen et al., 2007; Wang et al., 2012; Zou, 2012), and can use to control the density of pest populations with artificial releases. Since $A$. chinensis plays a vital role in the biocontrol of pests, researchers have investigated environmental (Song et al., 2010) and dietary (Zou et al., 2015; Li et al., 2016, 2018) conditions to optimize the mass production of $A$. chinensis. Some researchers found no distinct difference in developmental duration, survival rate, fecundity, and egg viability of A. chinensis reared on diets with different nutrient composition ( $\mathrm{Li}$ et al., 2016). However, many insect herbivores have evolved counter-adaptations to overcome the plant defence. These adaptations include host plant choice, non-disruptive feeding guilds and various physiological adaptations as well as metabolic enzymatic strategies of the insect's digestive system (Pentzold et al., 2014). There may be an adaptation to the cold tolerance for the various food to the polyphagous $A$. chinensis.

Unlike rearing at normal temperature, consequences of cold storage may result from a combination of both chill-injuries and exhaustion of energy reserves (Colinet et al., 2006). Substances such as glycogen, lipids, glycerol and cell membrane construction maybe activated in response to cold exposure as a method to help insects survive in the adverse environments (Feng et al., 2014). Therefore, the accumulation and the metabolic rate of these substances in insects affect their cold storage tolerance. In this study, we focus on the effects of different diets on the response of $A$. chinensis to cold storage treatments, including its physiological and biochemical responses. We hope to advance diet formulation as a way to improve the use of cold storage for mass production of $A$. chinensis.

\section{Materials and methods}

\section{Experimental insects and diet}

Rearing A. chinensis

A. chinensis used for these studies originated from over-wintering adults collected from Ulmus pumila plantation (farmland shelterbelts) located in Linzi Town, Qian'an 


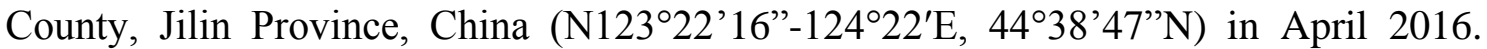
After diapause termination, colonies A. chinensis were continuously fed (ad libitum) either pupae of Antherea pernyi (diet AP) or pupae of Tenebrio molitor (diet TM) for 12 generations in insect rearing cages at the ambient temperature of $25 \pm 1{ }^{\circ} \mathrm{C}$, humidity of $65 \pm 5 \%$, and lighting of 16L: 8D (Figs. 1 and 2). For these studies, 3- to 7-day-old adults were collected after 12 generations of rearing on either A. pernyi (diet AP; 2,154 adults collected) or on $T$. molitor (diet TM; 2,436 adults collected).
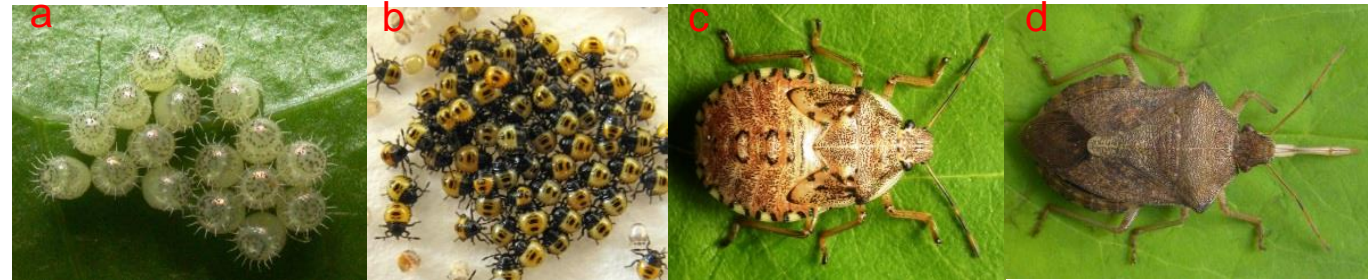

Figure 1. Morphological of A. chinensis (Fallou). a, Egg mass; b, First instar Nymph; c, third instar Nymph; $d$, Female adult

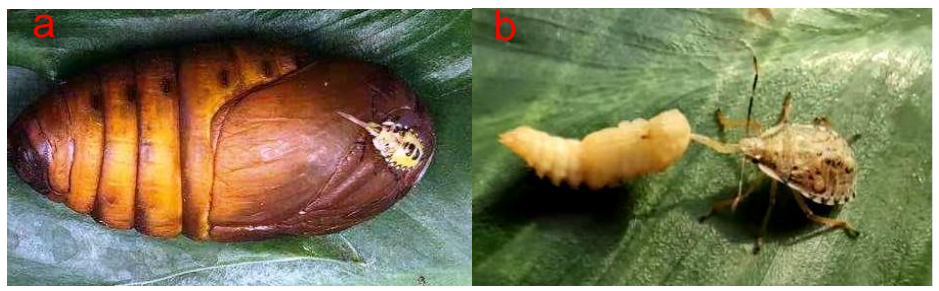

Figure 2. The nymph of A. chinensis feeding Antherea pernyi (a) and Tenebrio molitor (b)

\section{Nutrient component and content of two natural diets}

The pupae of $A$. pernyi (diet AP) and T. molitor (diet TM) were collected from the rearing factory. After rinsing the pupae of A. pernyi (9) and T. molitor (120) were dried of any extraneous moisture using the filter paper, then labeled and weighted individually. The pupae were frozen dried at $-40{ }^{\circ} \mathrm{C}$ for $72 \mathrm{~h}$, weighted again for calculating the water content, then grounded and analyzed the nutrient component using the method described by Jiang et al. (2016). The nutrients of pupae of $A$. pernyi and $T$. molitor were showed in Table 1.

\section{Design of cold storage treatment}

20 adults for each treatment were placed in a culture dish $(11 \mathrm{~cm}$ in diameter) with filter paper at the bottom, then were placed into a low temperature incubator without illumination at the temperature of $4 \pm 1{ }^{\circ} \mathrm{C}$ and the humidity of $65 \pm 5 \% \mathrm{RH}$. The preliminary test showed no significant difference in biological indexes for male and female adults fed either AP or TM and subjected to 3 weeks of cold treatment. Therefore, the minimum cold storage period was set as 30 days without considering the sex, followed by 10-day extensions in cold storage period until all adults in the treatment dead. Five cold storage periods were established with a control group held at $25 \pm 1{ }^{\circ} \mathrm{C}$ and humidity of $65 \pm 5 \% \mathrm{RH}$. All the A. chinensis were provided with 
sufficient water but no food during the cold storage, and were discarded after measuring biological indexes (Coudron et al., 2007).

At each cold storage time point, 400 adults were collected for survival rate measurement from each diet treatment after holding at $25 \pm 1{ }^{\circ} \mathrm{C}$ and $65 \pm 5 \% \mathrm{RH}$ for $24 \mathrm{~h}$. Then 20 pairs of survivors (one male and one female per pair) were placed in paper cups $(7 \mathrm{~cm}$ in diameter and $8 \mathrm{~cm}$ in height) for each diet treatment. Fresh diet (1 silkworm pupa or 4 mealworm pupae) and water via a wet cotton ball was provided every day in each cup. The quantity of eggs laid, the time of egg oviposition, and time of death were recorded for two weeks. Egg viability was determined using 15 to 20 eggs from each cup.

Table 1. Main ingredients and amounts of Antherea pernyi (AP) and Tenebrio molitor (TM)

\begin{tabular}{|c|c|c|c|}
\hline \multirow{2}{*}{\multicolumn{2}{|c|}{ Ingredient }} & \multicolumn{2}{|c|}{ Amount } \\
\hline & & \multirow{2}{*}{$\begin{array}{c}\mathbf{A} \mathbf{P}^{*} \\
75.10\end{array}$} & \multirow{2}{*}{$\begin{array}{l}\text { TM}^{*} \\
62.50\end{array}$} \\
\hline Water (\%) & & & \\
\hline Protein $(\%)$ & & 12.90 & 16.80 \\
\hline Carbohydrates (\%) & & 1.90 & 10.00 \\
\hline Lipids (\%) & & 7.80 & 8.60 \\
\hline \multirow{7}{*}{ Fatty acid (percentage of total fat) (\%) } & $<\mathrm{C}^{0} 16$ & 1.20 & 1.50 \\
\hline & $\mathrm{C}^{0} 16$ & 18.10 & 23.60 \\
\hline & $\mathrm{C}^{0} 18$ & 6.70 & 1.40 \\
\hline & $<\mathrm{C}^{1} 18$ & 5.60 & 4.50 \\
\hline & $\mathrm{C}^{1} 18$ & 54.00 & 44.70 \\
\hline & $\mathrm{C}^{2} 18$ & 10.70 & 24.10 \\
\hline & $\mathrm{C}^{3} 18$ & 2.00 & 1.50 \\
\hline \multirow{10}{*}{ Mineral (mg/100 g) } & $\mathrm{K}$ & 272.00 & 1420.00 \\
\hline & $\mathrm{Na}$ & 140.20 & 63.20 \\
\hline & $\mathrm{Ca}$ & 81.00 & 125.00 \\
\hline & $\mathrm{Mg}$ & 103.00 & 185.00 \\
\hline & $\mathrm{Fe}$ & 2.60 & 6.40 \\
\hline & $\mathrm{Mn}$ & 0.64 & 1.50 \\
\hline & $\mathrm{Zn}$ & 6.17 & 11.90 \\
\hline & $\mathrm{Cu}$ & 0.53 & 4.30 \\
\hline & $\mathrm{P}$ & 207.00 & 691.00 \\
\hline & $\operatorname{Se}(\mu \mathrm{g})$ & 11.10 & 47.50 \\
\hline \multirow{5}{*}{ Vitamins (mg/100 g) } & B1 & 0.11 & 0.07 \\
\hline & B2 & 6.39 & 0.52 \\
\hline & $\mathrm{A}(\mu \mathrm{g})$ & 0.25 & 1.90 \\
\hline & E & 5.34 & 1.90 \\
\hline & $\mathrm{D}(\mu \mathrm{g})$ & - & 10.45 \\
\hline
\end{tabular}

\section{Influences of different diets on biochemical indexes of A. chinensis}

The physiological and biochemical indexes related to cold resistance of adult of $A$. chinensis were measured after 30-days cold storing period, including super-cooling points, low-molecular carbohydrates, fatty acids and glycerol, nutrient absorption and enzyme activities. 


\section{Super-cooling points (SCPS) and freezing points (FPs)}

Super-cooling and freezing points were determined for 40 adults from each diet after 30-day cold storage treatment. Individual adult was dried of any extraneous moisture, placed in a centrifuge tube and fixed to a thermocouple attached to an automatic recorder (UR100, Model 4152, Yokogawa Electric Co., Seoul, Korea) via a bridge. The thermocouple with the adult was lowered into a freezing chamber (VM04/100, Heraeus Co., Germany) at $0{ }^{\circ} \mathrm{C}$ for $20 \mathrm{~min}$, and then was cooled to $-40{ }^{\circ} \mathrm{C}$ at a rate of $1{ }^{\circ} \mathrm{C} / \mathrm{min}$, and the decreasing body temperatures were measured. The SCPs was taken as the lowest temperature before the increase in temperature caused by the latent heat of crystallization (Mohammadzadeh and Izadi, 2016).

\section{Low-molecular-weight carbohydrates in the insect body}

The content of low-molecular-weight carbohydrates were measured in 300 adults for each diet after 30-day cold storage treatment, freeze-dried for $48 \mathrm{~h}(2.5 \mathrm{~L}$ FreeZone, LabconcoInc., USA), ground, and then measured by the method as described by Heydari and Izadi (2014). Briefly, $1 \mathrm{~g}$ of dried powder of A. chinensis was extracted with $20 \mathrm{ml}$ of $80 \%$ ethanol, and heated at $75{ }^{\circ} \mathrm{C}$ for $20 \mathrm{~min}$ in a water bath, and then centrifuged for $3 \mathrm{~min}$ at $10000 \mathrm{rpm}$. The supernatant was analyzed with the Agilent 1200 liquid chromatograph (Agilent Technologies Inc., USA) for determining contents of trehalose, glucose, mannitol, sorbitol, and fructose. The other portion of freeze-dried powder of A. chinensis were used to the measurement of glycerol content and fatty acid content.

\section{Glycerol content in the insect body}

Briefly, $1 \mathrm{~g}$ of freeze-dried powder of A. chinensis was extracted with $1 \mathrm{ml}$ of distilled water using a glass hand homogenizer placed in an ice bath and centrifuged at $4{ }^{\circ} \mathrm{C}$ and $5000 \mathrm{rpm}$ for $15 \mathrm{~min}$. The supernatant was analyzed with the Glycerol Assay Kit (Catalog Number MAK117, Storage Temperature -20 ${ }^{\circ} \mathrm{C}$, Sigma-Aldrich, St. Louis, USA). The procedure followed the instruction of the test kit (Jehrke et al., 2018).

\section{Fatty acids contents in the insect body}

Briefly, $0.5 \mathrm{~g}$ of freeze-dried powder of A. chinensis was extracted with a $2: 1 \mathrm{v}: \mathrm{v}$ solution of chloroform-methanol (Gołębiowski et al., 2008). Fatty acids in the organic phase were methyl esterified, and quantified by gas chromatography (Agilent 7890A, Agilent Technologies Inc., USA; adopting fused-silica capillary column as chromatographic column, $100 \mathrm{~m} \times 0.25 \mathrm{~mm} \times 0.2 \mu \mathrm{m}$, CP-Sil 88, Chrompack; Agilent Technologies Inc., USA).

\section{Enzyme activities related to the transformation of cold-resistant substances}

For each enzyme activity analysis, 20 adults were pooled for each diet after 30-day cold storage treatment. The insects were grounded with the liquid nitrogen freezing grinder (JXFSTPRP-II-01 Shanghai Jingxin Co., LD, China). Briefly, $0.1 \mathrm{~g}$ of powder of $A$. chinensis was extracted with $0.9 \mathrm{ml}$ extracting solution using a glass hand homogenizer placed in an ice bath. Then centrifuged at $4{ }^{\circ} \mathrm{C}$ for $10 \mathrm{~min}$ with the speed $2500 \mathrm{rpm}$ for Catalase (CAT), Peroxidase (POD), total superoxide dismutase (T-SOD), $8000 \mathrm{rpm}$ for trehalase (THL) and Glyceraldehyde-3-phosphate dehydrogenase 
(GAPDH), $10000 \mathrm{rpm}$ for Trypsin, and $2000 \mathrm{rpm}$ for Adenosine triphosphatase (ATP) $\left(\mathrm{Na}^{+} \mathrm{K}^{+}\right.$-ATP, $\left.\mathrm{Ca}^{2+} \mathrm{Mg}^{2+}-\mathrm{ATP}\right)$, respectively. The extracted solution centrifuged at $4{ }^{\circ} \mathrm{C}$ and $16000 \mathrm{rpm}$ for $40 \mathrm{~min}$ for fatty acid synthetase (FAS). Then the supernatants were taken to prepare the samples for analyses enzyme activity analysis.

Trypsin activity, GAPDH activity, THL activity, and FAS activity were determined with a kit (Suzhou Keying Biotechnology Co., Ltd., Suzhou, China) according to the instruction; CAT, T-SOD, ATP, and POD activities were determined with a kit produced by Nanjing Jiancheng Bioengineering Institute (Nanjing, China) according to instruction.

\section{Data analysis}

Prior to analysis, data for survival rate, longevity, fertility, the time of egg oviposition, fecundity, egg viability were $\ln (x+1)$ transformed to achieve normality. The effect of diet and length of cold storage on cold tolerance of A. chinensis were analyzed using general linear models with LSD significant difference test $(\mathrm{P}<0.05)$. The effect of the length of cold storage was analyzed with non-parametric tests (Cruskal-Wallis rank-sum test) of multiple independent samples $(\mathrm{P}<0.05)$. The effect of diet on biological indexes (survival rate, longevity, fertility, egg oviposition time, fecundity, and egg viability), and biochemical indexes (super-cooling point, the content of micro-molecule carbohydrates, glycerol, and fatty acids) and enzyme activity were tested by the Independent sample $\mathrm{T}$ test $(\mathrm{P}<0.05)$. The analysis were performed using SPSS statistical software (SPSS 17.0 for windows, SPSS Inc., Chicago, USA).

Structural equation modeling (SEM) was used to evaluate the general hypothesis that carbohydrate, glycerol, saturated fatty acid (SFA), and unsaturated fatty acid (UFA) content of adult affect survival rate, longevity, fertility, fecundity, egg viability of $A$. chinensis. We hypothesized that the adaptations of metabolic enzymatic strategies of the A. chinensis induced by diet and cold treatments influenced the content of energy reserves, which then altered the cold tolerance of $A$. chinensis. We constructed an a priori model including possible causal relationships among predictors, i.e. the enzymatic activity was the main factor influencing the content of carbohydrates, glycerol and fatty acids induced by diet and cold treatments, which then influenced fertility, survival rate, egg viability, fecundity and changed super-cooling points (SCPs). All of the predicators were treated as observed variables. Finally our results only showed the significant biochemical pathways. Mardia's test was used to estimate the multivariate normality of the dataset. The model fitness was assessed using the $\chi 2$-test, comparative fit index (CFI), and root mean square error of approximation (RMSEA). The analysis was performed with SPSS AMOS 21.0 software (SPSS Inc., Hong Kong) using the "robust" maximum likelihood estimation procedures.

\section{Results}

\section{Effect of diet on the biological indexes after cold storage treatment}

The effect of diet and cold storage time on the survival rate, longevity, and female fertility, egg oviposition time, fecundity, and egg viability varied with the length of time in cold storage (Table 2). 


\section{Survival rate}

The length of time in cold storage significantly affected the survival rate of adults from colonies reared on either TM or AP (Table 2). The survival rate decreased significantly with increased time in cold storage (AP, $\mathrm{H}=32.125$, df $=5, \mathrm{P}<0.001$; $\mathrm{TM}, \mathrm{H}=32.224$, $\mathrm{df}=5, \mathrm{P}<0.001$ ). The effect of diet on survival rate varied with the length of time in cold storage (Fig. 3). The survival rate for TM was significantly higher than for AP (30-day, $\mathrm{F}=0.225, \mathrm{~T}=-2.573$, df $=10, \mathrm{P}=0.028 ; 40$-day, $\mathrm{F}=1.084, \mathrm{~T}=$ 2.349 , df $=10, \mathrm{P}=0.041$ ) at the 30-day and 40-day cold storage periods (Fig. 3). In addition, the survival rate for AP $(90.83 \%)$ was significantly lower than for the control group ( $\mathrm{P}<0.05)$, but the survival rate for TM $(96.67 \%)$ and the control group was not significantly different $(\mathrm{P}>0.05)$ at the 30 -day cold storage period. The survival rates for both AP and TM dropped to $12 \%$ at 70 -day cold storage period.

Table 2. Two-way ANOVA analysis of the biological indicators after cold storage

\begin{tabular}{|c|c|c|c|c|c|c|c|c|c|}
\hline \multirow{2}{*}{$\begin{array}{l}\text { Source of } \\
\text { variation }\end{array}$} & \multicolumn{3}{|c|}{ Survival (\%) } & \multicolumn{3}{|c|}{ Longevity (days) } & \multicolumn{3}{|c|}{ Fertility (\%) } \\
\hline & df & $\mathbf{F}$ & $\mathbf{P}$ & df & $\mathbf{F}$ & $\mathbf{P}$ & df & $\mathbf{F}$ & $\mathbf{P}$ \\
\hline $\mathrm{D}$ & 1 & 0.793 & 0.377 & 1 & 8.459 & 0.004 & 1 & 163.416 & $<0.001$ \\
\hline $\mathrm{S}$ & 5 & 107.164 & $<0.001$ & 4 & 81.820 & $<0.001$ & 4 & 706.635 & $<0.001$ \\
\hline $\mathrm{D} \times \mathrm{S}$ & 5 & 0.223 & 0.951 & 4 & 1.437 & 0.254 & 4 & 9.442 & $<0.001$ \\
\hline \multirow[t]{3}{*}{ Error } & 60 & & & 190 & & & 50 & & \\
\hline & \multicolumn{3}{|c|}{ Egg oviposition time } & \multicolumn{3}{|c|}{ Total fecundity } & \multicolumn{3}{|c|}{ Egg viability (\%) } \\
\hline & df & $\mathbf{F}$ & $\mathbf{P}$ & df & $\mathbf{F}$ & $\mathbf{P}$ & df & $\mathbf{F}$ & $\mathbf{P}$ \\
\hline D & 1 & 0.560 & 0.456 & 1 & 2.530 & 0.115 & 1 & 14.371 & $<0.001$ \\
\hline $\mathrm{S}$ & 4 & 32.740 & $<0.001$ & 4 & 285.966 & $<0.001$ & 4 & 131.935 & $<0.001$ \\
\hline $\mathrm{D} \times \mathrm{S}$ & 4 & 0.410 & 0.841 & 4 & 1.189 & 0.320 & 4 & 0.969 & 0.433 \\
\hline Error & 100 & & & 100 & & & 50 & & \\
\hline
\end{tabular}

D: diet; S: storage period

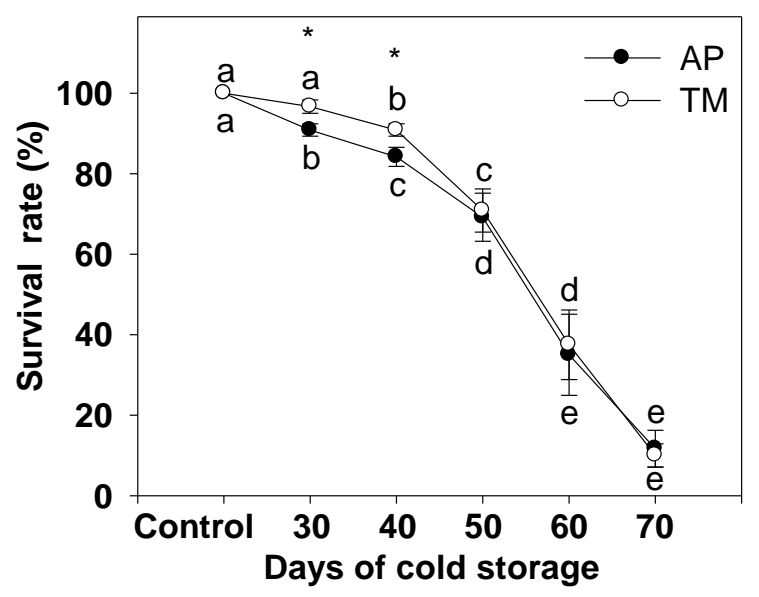

Figure 3. Survival of A. chinensis adults from colonies reared on diets Antherea pernyi (AP) and Tenebrio molitor (TM) after cold storage for different lengths of time at $4{ }^{\circ} \mathrm{C}$. The same colonies of A. chinensis reared at $25^{\circ} \mathrm{C}$ is shown as the control. The different letters represent significant difference among the different cold storage periods at $P<0.05$ level (Cruskal-Wallis Rank Sum Test). * represents a significant difference among the two diet treatments (T-test,

$$
P<0.05)
$$




\section{Longevity}

Both diet and length of cold storage showed a significant effect on the longevity of adults (Table 2). The longevity of adults for both diets significantly decreased with the increasing length of time in cold storage (AP, $\mathrm{H}=109.548, \mathrm{df}=5$, $\mathrm{P}<0.001$; TM, $\mathrm{H}=107.922, \mathrm{df}=5, \mathrm{P}<0.001$ ), which was lower than 3 days at 60 day cold storage period (Fig. 4). Overall, the longevity of the adult for TM was higher than for AP at all the cold storage time periods and the control group (Fig. 4). Moreover the differences in the longevity of adults for both diets were significant at 30-day and 50-day cold storage periods, respectively (30-day, $\mathrm{F}=11.350, \mathrm{~T}=-2.439, \mathrm{df}=38, \mathrm{P}=0.019 ; 50$-day, $\mathrm{F}=0.417, \mathrm{~T}=-4.09, \mathrm{df}=38$, $\mathrm{P}<0.001$ ) (as shown in Fig. 4).

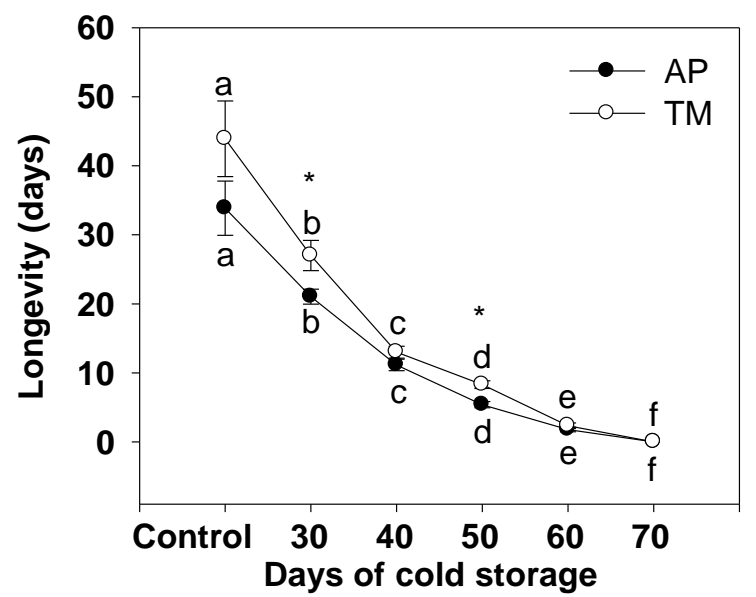

Figure 4. Longevity of A. chinensis adults from colonies reared on diets Antherea pernyi (AP) and Tenebrio molitor (TM) after cold storage for different lengths of time at $4{ }^{\circ} \mathrm{C}$. The different letters represent significant difference among the different cold storage periods at $P<0.05$ level (Cruskal-Wallis Rank Sum Test). * represents a significant difference among the two diet treatments $(T$-test, $P<0.05)$

\section{Fertility}

Both diet and cold storage time showed a significant effect on fertility (Table 2). The fertility declined with the increasing cold storage time for both diets compared to the control group reared on $25{ }^{\circ} \mathrm{C}$ (the fertility was $70.19 \%$ and $79.93 \%$ for AP and TM, respectively) (Fig. 5). After 60 days of cold storage, fertility had dropped to below $10 \%$ for both diet treatments (AP, $\mathrm{H}=34.208$, df $=5, \mathrm{P}<0.001$; $\mathrm{TM}$, $\mathrm{H}=33.388$, $\mathrm{df}=5, \mathrm{P}<0.001)$. The fertilities for TM were significantly higher than those for AP before cold storage (control, $\mathrm{F}=0.243, \mathrm{~T}=-6.247$, $\mathrm{df}=10$, $\mathrm{P}<0.001$ ), and from the 30-day to 50-day cold storage period (30-day, $\mathrm{F}=1.546$, $\mathrm{T}=-6.043, \mathrm{df}=10, \mathrm{P}<0.001 ; 40$-day, $\mathrm{F}=1.091, \mathrm{~T}=-5.975, \mathrm{df}=10, \mathrm{P}<0.001 ;$ 50-day, $\mathrm{F}=0.069, \mathrm{~T}=-8.344, \mathrm{df}=10, \mathrm{P}<0.001)$ (Fig. 5). 


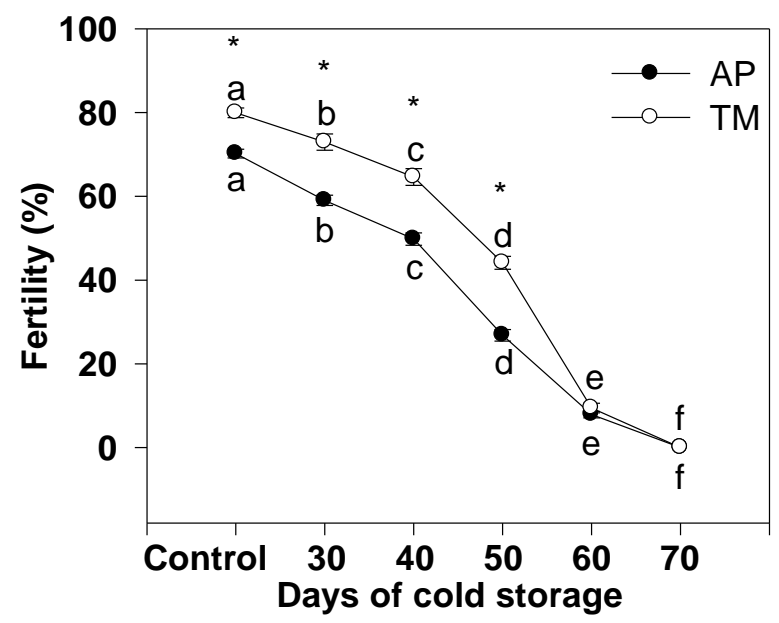

Figure 5. Fertility of A. chinensis adult from colonies reared on Antherea pernyi (AP) and Tenebrio molitor (TM) after cold storage for different lengths of time at $4{ }^{\circ} \mathrm{C}$. The different letters represent significant difference among the different cold storage periods at $P<0.05$ level (Cruskal-Wallis Rank Sum Test). * represents a significant difference among the two diet treatments $(T$-test, $P<0.05)$

\section{Egg oviposition time}

The cold storage period had a significant effect on the time of egg oviposition (Table 2), which decreased with the increasing of the cold storage time for both diets (AP, $\mathrm{H}=46.692$, df = 5, $\mathrm{P}<0.001 ; \mathrm{TM}, \mathrm{H}=42.356$, df = 5, $\mathrm{P}<0.001$ ) (Fig. 6). There was no significant effect of diet on the time of egg oviposition at all cold storage periods $(\mathrm{P}>0.05)$ (Table 2; Fig. 6).

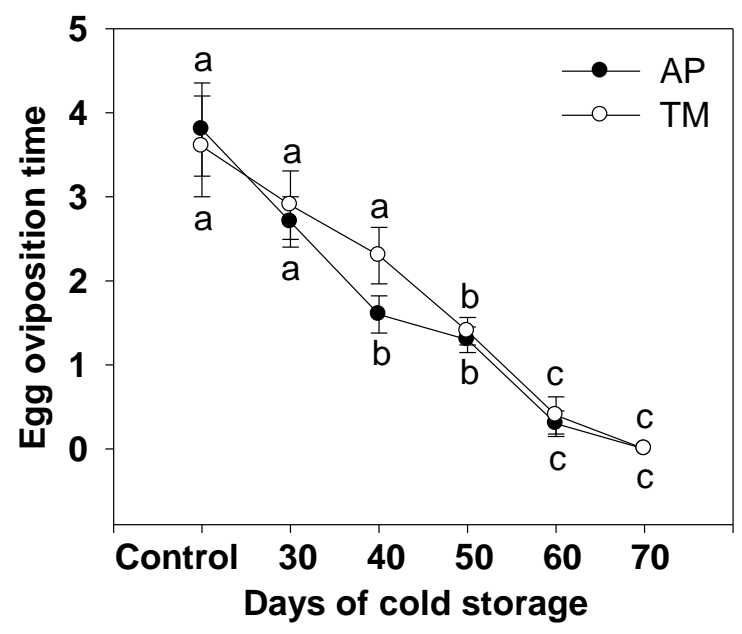

Figure 6. Egg oviposition time of A. chinensis adults from colonies reared on Antherea pernyi (AP) and Tenebrio molitor (TM) after cold storage for different lengths of time at $4{ }^{\circ} \mathrm{C}$. The different letters represent significant difference among the different cold storage periods at $P<0.05$ level (Cruskal-Wallis Rank Sum Test) 


\section{Fecundity}

Length of cold storage had a significant effect on the fecundity of $A$. chinensis reared on either diets (Table 2). Overall, fecundity decreased with the increasing length of time in cold storage ( $\mathrm{AP}, \mathrm{H}=56.991$, $\mathrm{df}=5, \mathrm{P}<0.001 ; \mathrm{TM}, \mathrm{H}=55.013$, df $=5, \mathrm{P}<0.001$ ) (Fig. 7). There was no significant difference in the fecundity for AP and TM (Table 2), but the average fecundity for TM was significant higher (by 30\%) than that for AP at 40-day cold storage $(\mathrm{F}=0.752, \mathrm{~T}=-3.018, \mathrm{df}=18, \mathrm{P}=0.008)($ Fig. 7$)$.

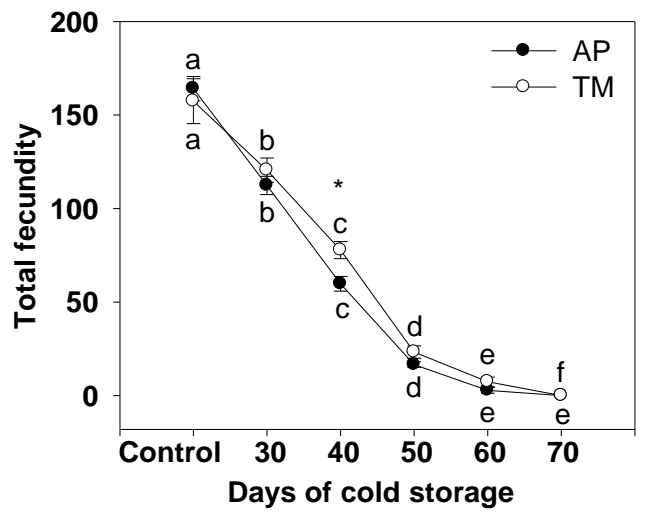

Figure 7. Fecundity of A. chinensis adults from colonies reared on Antherea pernyi (AP) and Tenebrio molitor (TM) after cold storage for different lengths of time at $4{ }^{\circ} \mathrm{C}$. The different letters represent significant difference among the different cold storage periods at $P<0.05$ level (Cruskal-Wallis Rank

Sum Test). * represents a significant difference among the two diet treatments $(T$-test, $P<0.05)$

\section{Egg viability}

Both diet and length of time in cold storage had a significant effect on egg viability for A. chinensis (Table 2). Egg viability declined for both diet treatments with the increasing length of time in cold storage (AP, $\mathrm{H}=33.379$, df $=5, \mathrm{P}<0.001$; TM, $\mathrm{H}=33.292$, $\mathrm{df}=5, \mathrm{P}<0.001$ ) (Fig. 8). Egg viability for TM was higher than for AP, but the significant difference only occurred at 40 -day cold storage period $(\mathrm{F}=0.222$, $\mathrm{T}=-4.592, \mathrm{df}=10, \mathrm{P}=0.001)($ Fig. 8).

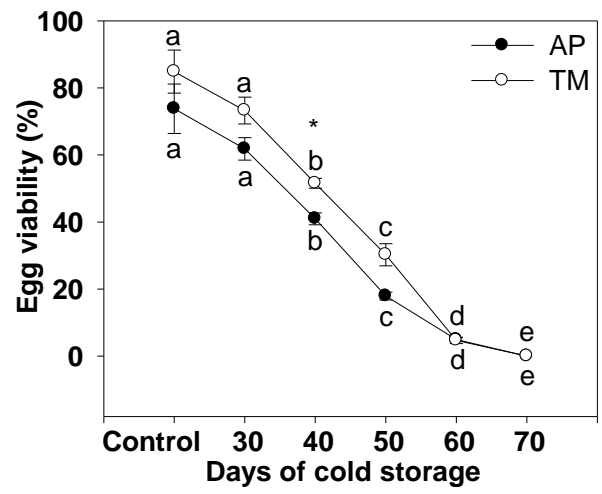

Figure 8. Egg viability of A. chinensis adults from colonies reared on Antherea pernyi (AP) and Tenebrio molitor (TM) after cold different lengths of time in cold storage at $4{ }^{\circ} \mathrm{C}$. The different letters represent significant difference among the different cold storage periods at $P<0.05$ level (CruskalWallis Rank Sum Test). * represents a significant difference among the two diet treatments (T-test,

$$
P<0.05)
$$




\section{Effect of diet and lengths of time in cold storage on physiological indexes}

\section{Super-cooling and freezing points}

Diet treatments had a significant effect on the super-cooling and freezing points (SCPs, $\mathrm{F}=0.399, \quad \mathrm{~T}=19.294, \quad \mathrm{df}=18, \quad \mathrm{P}<0.001 ; \quad \mathrm{FPs}, \quad \mathrm{F}=0.336, \quad \mathrm{~T}=16.512, \quad \mathrm{df}=18$, $\mathrm{P}<0.001$ ). The super-cooling and freezing points for TM were $20 \%$ lower than for AP (Fig. 9).

\section{Low-molecular-weight sugars and glycerol}

Low-molecular-weight sugars (trehalose, mannitol, sorbitol) and glycerol were significantly higher for TM than AP, by $31 \%, 228 \%, 211 \%$ and $56 \%$, respectively (Fig. 10, Trehalose, $\mathrm{F}=0.238, \mathrm{~T}=-3.153$, $\mathrm{df}=8, \mathrm{P}=0.014 ;$ Mannitol, $\mathrm{F}=38.515$, $\mathrm{T}=-3.157, \quad \mathrm{df}=8, \mathrm{P}=0.013 ;$ Sorbitol, $\mathrm{F}=0.436, \mathrm{~T}=-9.711, \mathrm{df}=8, \mathrm{P}<0.001 ;$ Glycerol, $\mathrm{F}=2.860, \mathrm{~T}=-133.056, \mathrm{df}=8, \mathrm{P}<0.001)$.

\section{Fatty acids}

There was no significant difference in the total content of fatty acids for AP and TM $(\mathrm{F}=6.51, \mathrm{~T}=0.51, \mathrm{df}=6.06, \mathrm{P}=0.63)$. However, the content of saturated fatty acids for AP was significantly higher by $129 \%$ than for $\mathrm{TM}(\mathrm{F}=21.65, \mathrm{~T}=12.95$, $\mathrm{df}=4.72$, $\mathrm{P}<0.001)$, but the content of unsaturated fatty acids were significantly lower by $28 \%$ than for $\mathrm{TM}(\mathrm{F}=1.97, \mathrm{~T}=6.5, \mathrm{df}=8, \mathrm{P}<0.001)($ Table 3).

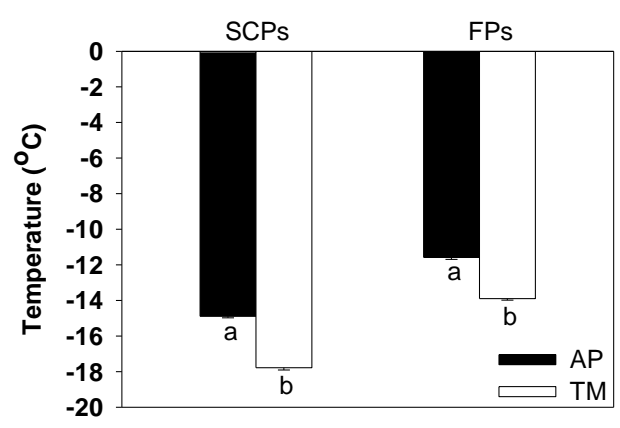

Figure 9. Super-cooling and freezing points of A. chinensis adults from colonies reared Antherea pernyi (AP) and Tenebrio molitor (TM) after cold storage for 30 days at $4{ }^{\circ} \mathrm{C}$. Different letters indicate significant differences between diet treatments at $P<0.05$ level (T-test)

Table 3. Fatty acid content in A. chinensis adults from colonies reared on Antherea pernyi $(A P)$ and Tenebrio molitor (TM) after cold storage for 30 days at $4{ }^{\circ} \mathrm{C}$ (means \pm standard error)

\begin{tabular}{c|c|c}
\hline \multirow{2}{*}{ Fatty acids } & \multicolumn{2}{|c}{ Contents $(\mathbf{m g} / \mathbf{g})$} \\
\cline { 2 - 3 } & Antherea pernyi $($ AP) & Tenebrio molitor $(\mathbf{T M})$ \\
\hline$\Sigma$ Fatty acid & $77.66 \pm 3.53 \mathrm{a}$ & $75.63 \pm 1.86 \mathrm{a}$ \\
$\Sigma$ Saturated fatty acids & $34.08 \pm 1.42 \mathrm{a}$ & $14.89 \pm 0.43 \mathrm{~b}$ \\
$\Sigma$ Unsaturated fatty acids & $43.58 \pm 2.15 \mathrm{a}$ & $60.74 \pm 1.54 \mathrm{~b}$ \\
$\Sigma$ Monounsaturated fatty acids & $6.34 \pm 0.29 \mathrm{a}$ & $20.59 \pm 0.95 \mathrm{~b}$ \\
$\Sigma$ Polyunsaturated fatty acids & $37.23 \pm 1.86 \mathrm{a}$ & $40.15 \pm 0.78 \mathrm{a}$ \\
\hline
\end{tabular}

Different letters indicate significantly statistical difference at the same row at $\mathrm{P}<0.05$ (T-test) 


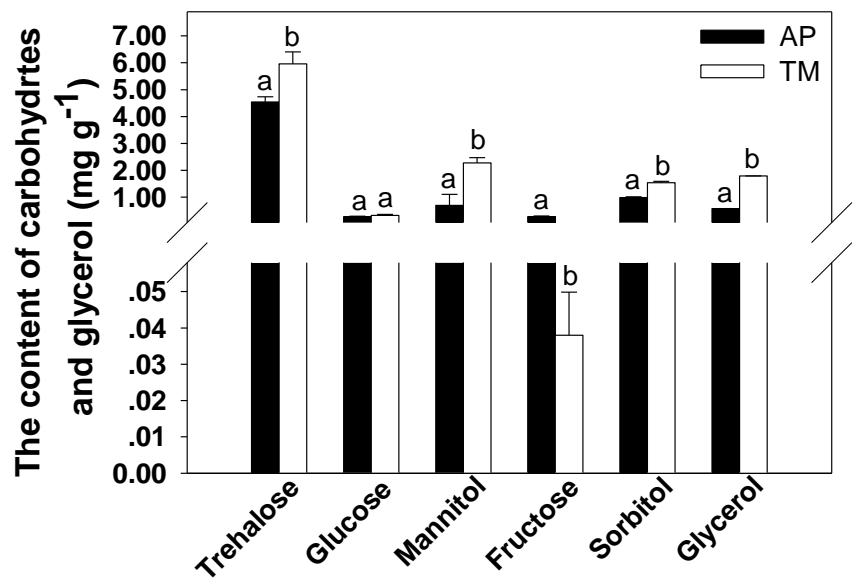

Figure 10. Low-molecular-weight sugars and glycerol content of A. chinensis adults from colonies reared on Antherea pernyi (AP) and Tenebrio molitor (TM) after cold storage for 30 days at $4{ }^{\circ} \mathrm{C}$. Different letters indicate significant differences between diet treatments at $P<0.05$ level (T-test)

\section{Enzyme activities}

The effect of diet on the enzyme activities in adults varied among the different enzymes (Fig. 11). Activities of GAPDH, $\mathrm{Na}^{+} \mathrm{K}^{+}$-ATPase, and $\mathrm{Ca}^{2+} \mathrm{Mg}^{2+}$-ATPase for TM were greatly higher, by 2.53 times, 2.00 times and 3.10 times, respectively, than for AP (GAPDH, $\mathrm{F}=0.029, \mathrm{~T}=40.782, \mathrm{df}=10, \mathrm{P}<0.001 ; \mathrm{Na}^{+} \mathrm{K}^{+}$-ATPase, $\mathrm{F}=0.309$, $\mathrm{T}=7.741, \quad \mathrm{df}=10, \quad \mathrm{P}<0.001 ; \mathrm{Ca}^{2+} \mathrm{Mg}^{2+}$-ATPase, $\mathrm{F}=4.774, \mathrm{~T}=14.35, \quad \mathrm{df}=10$, $\mathrm{P}<0.001)$. The FAS activity for AP was significantly lower, by $37 \%$, than for TM $(\mathrm{F}=1.285, \mathrm{~T}=-5.410, \mathrm{df}=10, \mathrm{P}<0.001)$.

\section{The relationships between diets induced factors and cold tolerance}

The SEM revealed that the predictors explained $50 \%$ of the variation in diet effect (Fig. 12). The content of glycerol, SFA and UFA directly contributed to the survival rate of A. chinensis. Activities of GAPDH and FAS were associated with the survival rate through the content of SFA and UFA, respectively. It was worth noting that diet influenced the survival rate of $A$. chinensis indirectly through the activity of GAPDH and the content of glycerol. The content of fructose directly contributed to the fertility, and the activity of $\mathrm{Ca}^{2+} \mathrm{Mg}^{2+}$-ATPase was associated with the fertility through the content of fructose. Diet influenced the fertility of $A$. chinensis indirectly through the activity of $\mathrm{Ca}^{2+} \mathrm{Mg}^{2+}$-ATPase. The content of glycerol, fructose, sorbitol, SFA and UFA directly contributed to SCPs. And the activity of $\mathrm{Ca}^{2+} \mathrm{Mg}^{2+}$-ATPase was associated with SCPs through the content of fructose, the activities of GAPDH and FAS was associated with SCPs through the content of SFA and UFA, respectively. Diet influenced SCPs of A. chinensis indirectly through the activities of $\mathrm{Ca}^{2+} \mathrm{Mg}^{2+}$-ATPase and GAPDH, and the content of glycerol, sorbitol and UFA (Fig. 12).

\section{Discussion}

Response to cold storage can be a combination of adaptation to low temperatures and to starvation (Renault, 2003). As part of the adaptation, insects require a large amount 
of energy, which is derived solely from metabolic stores (lipids, proteins and eventually glycogen), and, therefore, body tissues are depleted because of catabolic activities (Hervant et al., 1999; Wang et al., 2017). With the depletion of energy reserves, starvation periods will have dramatic consequences on reproduction in adults (Leather, 1984).

Developmental and reproductive indexes used during cold storage can be affected by the diet consumed prior to the cold treatment. Previous studies demonstrated that species, diet, temperature and length-of-time affected the result of cold storage for insects (Colinet and Boivin, 2011; Koštál et al., 2016). We found that storage at $4{ }^{\circ} \mathrm{C}$ for less than 30 days had no significant effect on most biological indexes that we measured. However, survival rate, longevity, female fertility rate, fecundity, egg viability and time of oviposition for adults from colonies reared on the two diets we tested were affected when cold storage was extended beyond 30 days. Survival rate and longevity for TM were higher than for AP beyond 30-day cold storage. In contrast, the fecundity was significantly higher for AP than TM at 40-day cold storage.

(a) GAPDH

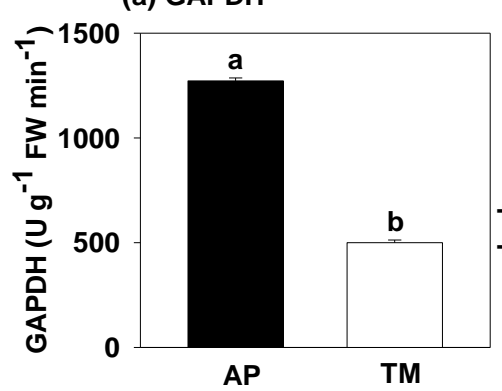

(d) POD

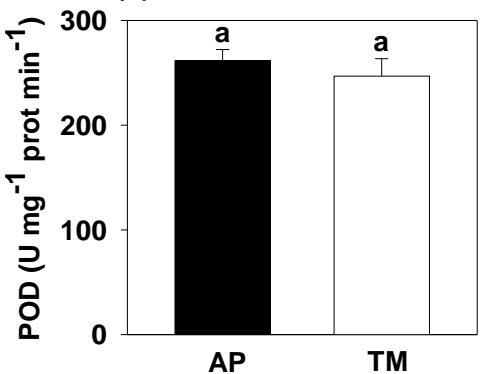

(g) THL

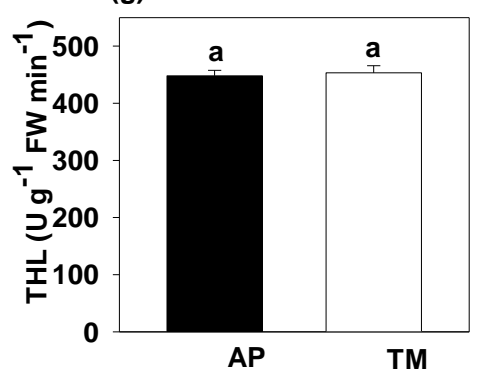

(b) $\mathrm{Na}^{+} \mathrm{K}^{+}$-ATPase

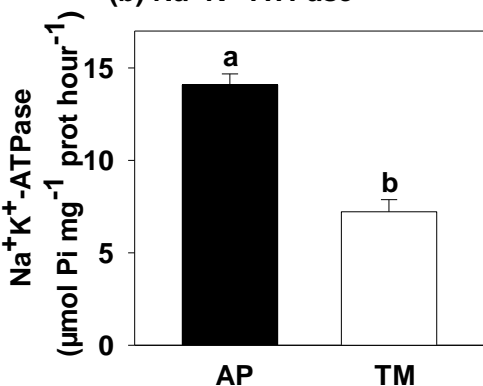

(e) T-SOD

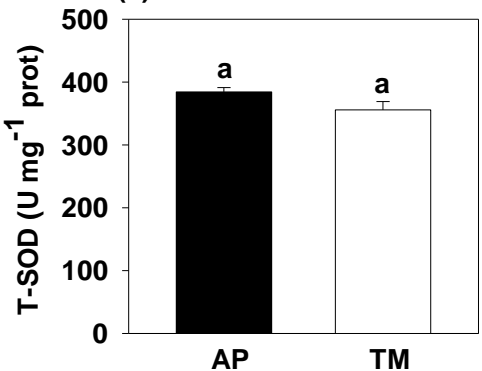

(h)Trypsin

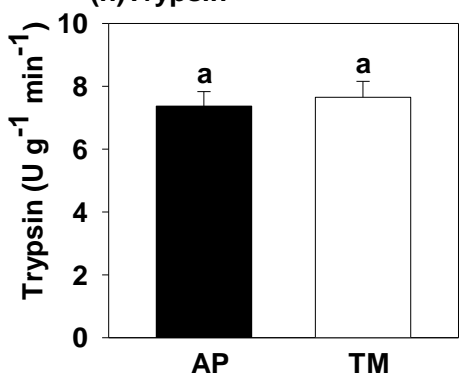

(c) $\mathrm{Ca}^{2+} \mathrm{Mg}^{2+}-$ ATPase

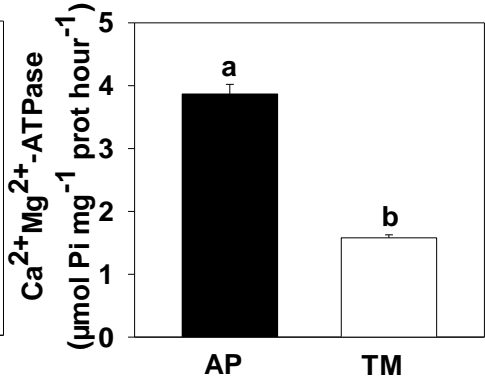

(f) CAT

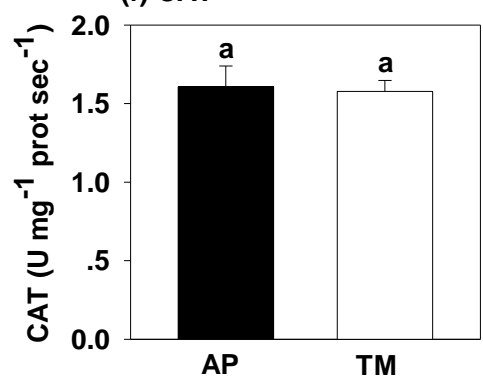

(i) FAS

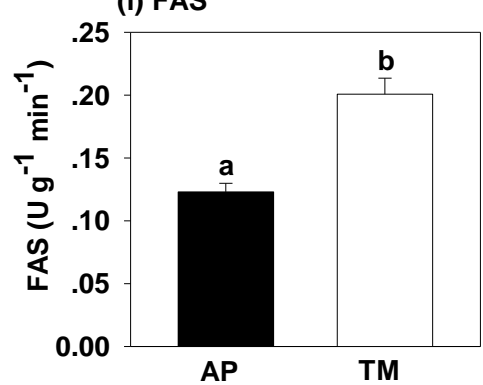

Figure 11. Enzymatic activity of A. chinensis adult fed on Antherea pernyi (AP) and Tenebrio molitor (TM) after cold storage 30 days at $4{ }^{\circ} \mathrm{C}$. (a) GAPDH; (b) Na+ $\mathrm{K}^{+}$ATPase; (c) $\mathrm{Ca}^{2+} \mathrm{Mg}^{2+}$ ATPase; (d) POD; (e) T-SOD; (f) CAT; ( $g$ ) THL; ( h) Trysin; (i) FAS. Different letters indicate significant differences between diet treatments at $P<0.05$ level ( $T$-test) 


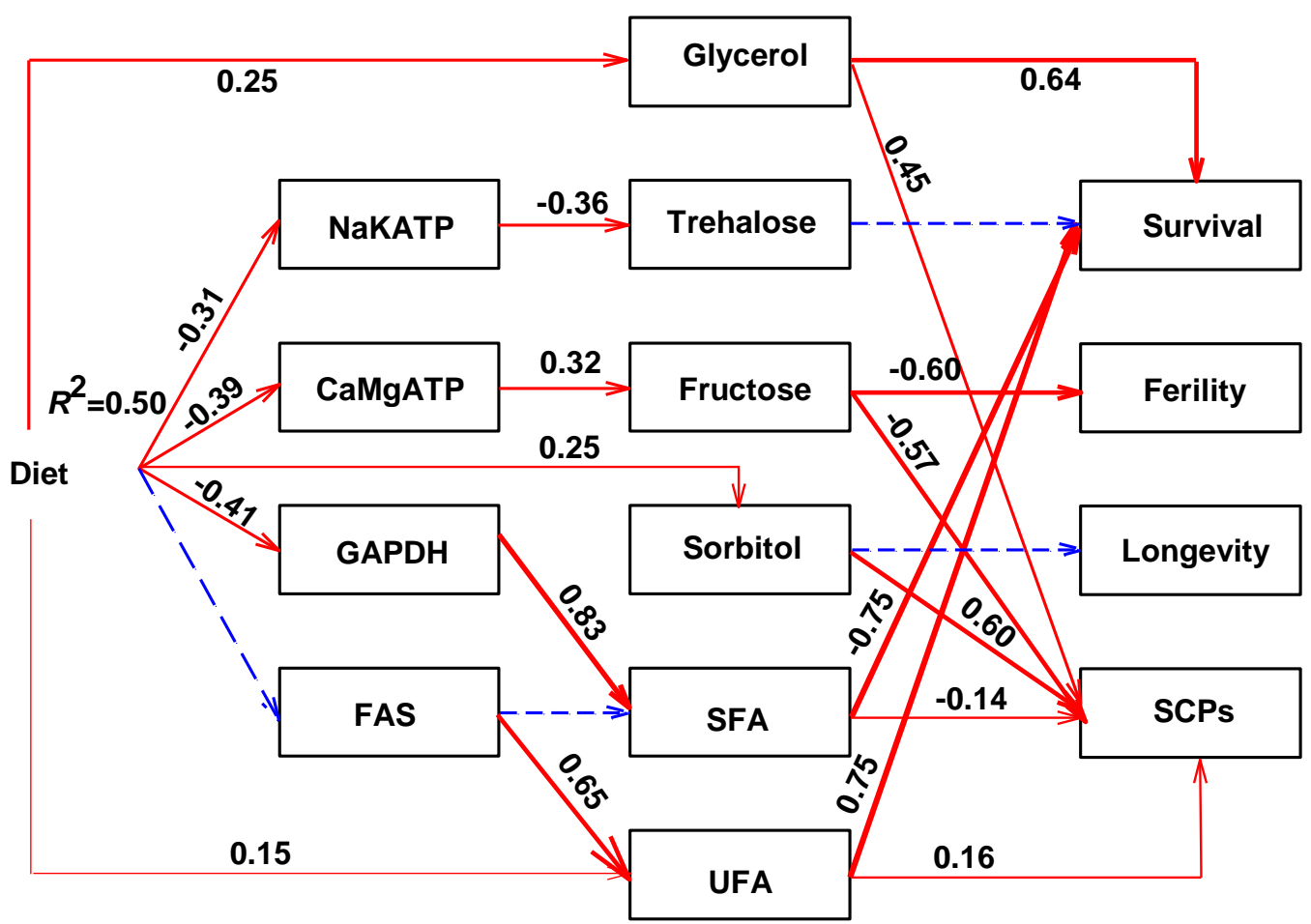

Figure 12. Structural equation model showing the potential mechanism of diet effects on the cold tolerance of $A$. chinensis $\left(\chi^{2}=73.416 ; d f=72 ; P=0.654 ; C F I=1.000\right.$;

RMSEA $=0.000)$. Arrow thickness represents the magnitude of the path coefficient, red solid

line arrows represent significant paths $(P<0.05)$, and blue dotted lines represent non-

significant paths. SFA: saturated fatty acid, UFA: unsaturated fatty acid, SCPs: super-cooling points

The quality of food consumed prior to cold storage was an important endogenous factor affecting the cold storage tolerance of insects (Ayrinhac et al., 2004; Coudron et al., 2009; Li et al., 2014). The nutrient content of food not only influence the storage of energy-related substances (such as low-molecule-weight hydrocarbons, glycerol, and lipids, etc.) before cold storage (Liu et al., 2009; Mohammadzadeh and Izadi, 2018), but also the metabolic processes related to energy for insects during the cold storage (Han and Bauce, 1998; Naya et al., 2007; Teets and Denlinger, 2014). Those changes in the physiological and metabolic processes have been credited with cold tolerance in a polyphagous insect herbivore (Hunter and McNeil, 1997). In our research, the contents of proteins, fats, and carbohydrates in TM are higher than those in AP (Table 1). The different nutrients in food may influence the production and accumulation of lowmolecular-weight cryoprotectants in insects under cold stress (Storey and Storey, 1991; Liu et al., 2007). The trehalose, glucose, mannitol, sorbitol and glycerol are proved to be cryoprotectants for many insects (Renault et al., 2006; Clark and Worland, 2008; Teets and Denlinger, 2013). Increased energy reserves, including glycogen, glycerol and total proteins were correlated with cold tolerance in Drosophila melanogaster (Chen and Walker, 1993). The SEM revealed that the content of glycerol and fructose directly contributed to the survival rate and the fertility of A. chinensis. In addition, diet influenced the survival rate and SCPs of $A$. chinensis indirectly through the content of glycerol and sorbitol (Fig. 12). The higher contents of trehalose, mannitol, sorbitol and 
glycerol in A. chinensis adults from a colony reared on TM after cold storage may be one of the reason that greater cold tolerance of A. chinensis fed on TM.

There were no significant differences in the total amount of fatty acids in adults from colonies reared on either of the two diets and subsequently exposed to the cold storage treatment. However, the content of unsaturated fatty acid in adults from colonies reared on TM was higher by $39 \%$ than for AP. This difference, may account, in part, to the $20 \%$ lower super-cooling and freezing points of adults from colonies reared on TM and AP, and the SEM results showed that diet influenced SCPs of A. chinensis indirectly through the content of UFA (Fig. 12). Fatty acids are not only one of the substrates for synthesizing fats, but also one of the basic substances of cell membranes which are important for growth and fertility of insects (Chang and Vargas, 2007). More unsaturated fatty acids in the cell membrane of insects can accelerate the movement of energy substances such as glycerol, lipids and carbohydrates into the cells (Matsuo et al., 2019); and decrease the phase transition temperature of the cell membrane, which ensure that bio-membranes are stable at low temperatures to overcome adverse conditions (Kasamo et al., 1992; Worland, 2005). Therefore, the different contents of fatty acids in A. chinensis induced by the different diets may contribute to the survival effects manifested during cold storage, especially the content of unsaturated fatty acids that is positively related to the survival of $A$. chinensis, but the saturated fatty acids were negatively related to the survival of A. chinensis (Fig. 12). However, it remains to be determined if types and contents of fatty acids in insect are an adaptive advantage in surviving exposure to low temperatures.

When diets with high carbohydrates were fed to Drosophila melanogaster, the expression of multiple enzymes such as glucosidase used for glycolysis and fatty acid synthase for fatty acid synthesis increased significantly (Baker and Thummel, 2007; Matsuda et al., 2014), while the expression of many carbohydrases and lipases were repressed (Chng et al., 2014). Similarly, the contents of nutrients in the diet also impacted the activity of enzymes related to glycometabolism, fat metabolism, and vitellogenin formation in insects (Chang et al., 2010; Chng et al., 2016). In our research, the GAPDH (related to gluconeogenesis), $\mathrm{Na}^{+} \mathrm{K}^{+}$-ATPase and $\mathrm{Ca}^{2+} \mathrm{Mg}^{2+}$-ATPase enzymes (related to energy release and transmembrane transportation) and glycolyticrelated enzymes (energy source) in adults from colonies reared on AP were higher than those for TM, but the FAS activity was lower (Fig. 11).

In order to explain the effect diet type on the biological and biochemical parameters of $A$. chinensis, and explore the adaptations of $A$. chinensis to cold storage, we develop a conceptual model of the metabolic enzymatic strategies of the A. chinensis pathways that diet influence cold storage tolerance of insects. The SEM revealed that the diet influenced the survival rate, the fertility and SCPs of A. chinensis indirectly through the activities of GAPDH, FAS and $\mathrm{Ca}^{2+} \mathrm{Mg}^{2+}$-ATPase (Fig. 12). Those metabolic enzymatic activity (GAPDH, FAS and $\mathrm{Ca}^{2+} \mathrm{Mg}^{2+}$-ATPase) were related to energy reserves, the higher content of glycerol and sorbitol directly contributed to SCPs, which induced the greater cold tolerance of $A$. chinensis reared on TM.

\section{Conclusion}

The present study demonstrated a dietary effect on the response of adult A. chinensis to cold temperatures. The content of glycerol, trehalose, sorbitol and fatty acids (unsaturated and saturated) in the adults were identified as possibly contributing to cold 
tolerance and dietary content was shown as affecting the level of those substances in the adults, thus providing an explanation for the observed differences in responses to cold storage treatments. Those results suggest that the diet with higher content of carbohydrates and mineral in T. moliter (TM) could enhance the cold tolerance of $A$. chinensis by increasing energy reserves (glycerol, trehalose, sorbitol and unsaturated fatty acids) and decreasing super-cooling points. Our results are helpful for the selection of natural diet and the optimization of artificial diet for A. chinensis and other predatory insects. Using modern molecular biology technology such as nutrigenomics and metabonomics to analyze the influence of specific nutrients of diet on the synthesis and metabolism of cold resistant substances of insects, which would be beneficial to optimize the formula of insect artificial diet.

Acknowledgements. The project was financially supported by National Key R \& D Program of China (2018YFC1200400) and the National Natural Science Foundation of China (31300552).

Conflict of interests. The authors declare that there is no conflict of interests.

\section{REFERENCES}

[1] Ayrinhac, A., Debat, V., Gibert, P., Legout, H., Moreteau, B., Vergilino, R., David, J. R. (2004): Cold adaptation in geographical populations of Drosophila melanogaster: Phenotypic plasticity is more important than genetic variability. - Functional Ecology 18: 700-706.

[2] Baker, K. D., Thummel, C. S. (2007): Diabetic larvae and obese flies - emerging studies of metabolism in Drosophila. - Cell Metabolism 6: 257-266.

[3] Chai, X. M., He, Z. H., Jiang, P. (2000): Studies on natural enemies of Dendrolimus punctatus in Zhejiang Province. - Journal of Zhejiang Forestry Science \& Technology 20(4): 56-61 (in Chinese).

[4] Chang, C. L., Vargas, R. I. (2007): Wheat germ oil and its effects on a liquid larval rearing diet for oriental fruit flies (Diptera: Tephritidae). - Journal of Economic Entomology 100(2): 322-326.

[5] Chang, C. L., Coudron, T. A., Goodman, C., Stanley, D., An, S. H., Song, Q. S. (2010): Wheat germ oil in larval diet influences gene expression in adult oriental fruit fly. Journal of Insect Physiology 56(4): 356-365.

[6] Chang, Y. F., Tauber, M. J., Tauber, C. A. (1995): Storage of the mass-produced predator Chrysoperla carnea (Neuroptera: Chrysopidae): Influence of photoperiod, temperature, and diet. - Environmental Entomology 24: 1365-1374.

[7] Chen, C. P., Walker, V. K. (1993): Increase in cold-shock tolerance by selection of cold resistant lines in Drosophila melanogaster. - Ecological Entomology 18(3): 184-190.

[8] Chen, J., Zhang, J. P., Zhang, J. H., Tian, Y. H., Chao, X. Z., Li. G. W. (2007): Study on functional response of Arma chinensis to the adults of Monolepta hieroglyphica. Natural Enemies of Insects 29(4): 149-154 (in Chinese).

[9] Chng, W. B. A., BouSleiman, M. S., Schüpfer, F., Lemaitre, B. (2014): Transforming growth factor $\beta$ /activin signaling functions as a sugar-sensing feedback loop to regulate digestive enzyme expression. - Cell Reports 9: 336-348.

[10] Chng, W. B. A., Hietakangas, V., Lemaitre, B. (2016): Physiological Adaptations to Sugar Intake: New Paradigms from Drosophila melanogaster. - Trends in Endocrinology and Metabolism 28(2): 131-142.

[11] Clark, M. S., Worland, M. R. (2008): How insects survive the cold: molecular mechanisms - a review. - Journal of Comparative Physiology B 178(8): 917-933. 
[12] Colinet, H., Hance, T. (2010): Interspecific variation in the response to low temperature storage in different aphid parasitoids. - Annals of Applied Biology 156: 147-156.

[13] Colinet, H., Hance, T., Vernon, P. (2006): Water relations, fat reserves, survival, and longevity of a cold-exposed parasitic wasp Aphidius colemani (Hymenoptera: Aphidiinae). - Environmental Entomology 35(2): 228-236.

[14] Coudron, T. A., Ellersieck, M. R., Shelby, K. S. (2007): Influence of diet on long-term cold storage of the predator Podisus maculiventris (Say) (Heteroptera: Pentatomidae). Biological Control 42: 186-195.

[15] Coudron, T. A., Popham, H. J. R., Ellersieck, M. R. (2009): Influence of diet on cold storage of the predator Perillus bioculatus (F.). - BioControl 54: 773-783.

[16] Ergin, E., Uckan, F. (2003): Temperature and food source effects on adult longevity of Apanteles galleriae Wilkinson (Hymenoptera: Braconidae). - Environmental Entomology 32(3): 441-446.

[17] Feng, Y., Wang, J., Zong, S. (2014): Review of Insects overwintering stages and coldresistance strategies. - Chinese Agricultural Science Bulletin 30(9): 22-25 (in Chinese).

[18] Gołębiowski, M., Maliński, E., Boguś, M. I., Kumirska, J., Stepnowski, P. (2008): The cuticular fatty acids of Calliphora vicina, Dendrolimus pini and Galleria mellonella larvae and their role in resistance to fungal infection. - Insect Biochemistry and Molecular Biology 38: 619-627.

[19] Gotthard, K., Nylin, S. (1995): Adaptive plasticity and plasticity as an adaptation: a selective review of plasticity in animal morphology and life history. - Oikos 74: 3-17.

[20] Han, E., Bauce, E. (1998): Timing of diapause induction, metabolic changes and overwintering survival of the spruce budworm, Choristoneura fumiferana. - Ecological Entomology 23: 160-167.

[21] Hervant, F., Mathieu, J., Barre, H. (1999): Comparative study on the metabolic responses of subterranean and surface-dwelling amphipods to long-term starvation and subsequent refeeding. - Journal of Experimental Biology 202(24): 3587-3595.

[22] Heydari, M., Izadi, H. (2014): Effects of seasonal acclimation on cold tolerance and biochemical status of the carob moth, Ectomyelois ceratoniae (Zeller), last instar larvae. Bulletin of Entomological Research 104(5): 592-600.

[23] Hodkova, M., Socha, R. (1995): Effect of temperature on photoperiodic response in a selected 'non-dapause' strain of Pyrrhocoris apterus (Heteroptera). - Physiological Entomology 20: 303-308.

[24] Hunter, M. D., Mcneil, J. N. (1997): Host-plant quality influences diapause and voltinism in a polyphagous insect herbivore. - Ecology 78: 977-986.

[25] Jehrke, L., Stewart, F. A., Droste, A., Beller, M. (2018): The impact of genome variation and diet on the metabolic phenotype and microbiome composition of Drosophila melanogaster. - Scientific Reports 8: 6215.

[26] Jiang, X. J., Chen, T. H., Huang, Y., Luo, J. (2016): Analysis and evaluation of nutritional component of Galleria mellonella. - Guangxi Forestry Science 45(4): 452-454 (in Chinese).

[27] Kasamo, K., Kagita, F., Yamanishi, H., Sakaki, T. (1992): Low temperature-Induced changes in the thermotropic properties and fatty acid composition of the plasma membrane and tonoplast of cultured rice (Oryza sativa L.) Cells. - Plant and Cell Physiology 33: 609-616.

[28] Koštál, V., Korbelová, J., Poupardin, R., Moos, M., Šimek, P. (2016): Arginine and proline applied as food additives stimulate high freeze tolerance in larvae of Drosophila melanogaster. - The Journal of Experimental Biology 219(15): 2358-2367.

[29] Leather, S. R. (1984): Factors affecting pupal survival and eclosion in the pine beauty moth, Panolis flammea (D\&S). - Oecologia 63(1): 75-79.

[30] Leopold, R. A. (2007): Colony Maintenance and Mass-Rearing: Using Cold Storage Technology for Extending the Shelf-Life of Insects. - In: Vreysen, M. J. B., Robinson, A. 
S., Hendrichs, J. (eds.) Area-Wide Control of Insect Pests: From Research to Field Implementation. Springer, Heidelberg, pp. 149-162.

[31] Li, J. J., Zhang, C. H., Yi, Z. J., Ran, X. C., Zhang, L. S., Liu, C. X., Wang, M. Q., Chen, H. Y. (2016): Effects of three prey species on development and fecundity of the predaceous Stinkbug Arma chinensis (Hemiptera: Pentatomidae). - Chinese Journal of Biological Control 32(5): 553-561 (in Chinese).

[32] Li, X. P., Song, L. W., Chen, Y. Q., Li, Y. N., Zuo, T. T., Wu, S. A. (2018): Influence of different fatty acids in artificial diets on growth, development and fecundity of Arma chinensis. - Scientia Silvae Sinicae 54(6): 85-93 (in Chinese).

[33] Li, Y. Y., Zhang, L. S., Zhang, Q. R., Chen, H. Y., Denlinger, D. L. (2014): Host diapause status and host diets augmented with cryoprotectants enhance cold hardiness in the parasitoid Nasonia vitripennis. - Journal of Insect Physiology 70: 8-14.

[34] Liu, Z. D., Gong, P. Y., Wu, K. J., Wei, W., Sun, J. H., Li, D. M. (2007): Effects of larval host plants on over-wintering preparedness and survival of the cotton bollworm, Helicoverpa armigera (Hübner) (lepidoptera: noctuidae). - Journal of Insect Physiology 53: 1016-1026.

[35] Liu, Z. D., Gong, P. Y., Heckel, D. G., Wei, W., Sun, J. H., Li, D. M. (2009): Effects of larval host plants on over-wintering physiological dynamics and survival of the cotton bollworm, Helicoverpa armigera (Hübner) (Lepidoptera: Noctuidae). - Journal of Insect Physiology 55: 1-9.

[36] Matsuda, H., Yamada, T., Yoshida, M., Nishimura, T. (2015): Flies without trehalose. Journal of Biological Chemistry 290: 1244-1255.

[37] Matsuo, N., Nagao, K., Suito, T., Juni, N., Kato, U., Hara, Y., Umeda, M. (2019): Different mechanisms for selective transport of fatty acids using a single class of lipoprotein in Drosophila. - Journal of Lipid Research 60(7): 1199-1211.

[38] Mohammadzadeh, M., Izadi, H. (2016): Enzyme activity, cold hardiness, and supercooling point in developmental stages of Acrosternum arabicum (Hemiptera: Pentatomidae). - Journal of Insect Science 16: 1-6.

[39] Mohammadzadeh, M., Izadi, H. (2018): Different diets affecting biology, physiology and cold tolerance of Trogoderma granarium (Everts) (Coleoptera: Dermestidae). - Journal of Stored Products Research 76: 58-65.

[40] Naya, D. E., Lardies, M. A., Bozinovic, F. (2007): The effect of diet quality on physiological and life-history traits in the harvestman Pachylus paessleri. - Journal of Insect Physiology 53: 132-138.

[41] Pentzold, S., Zagrobelny, M., Rook, F., Bak, S. (2014): How insects overcome two-component plant chemical defence: plant $\beta$-glucosidases as the main target for herbivore adaptation. - Biological Reviews 89(3): 531-551.

[42] Renault, D., Hance, T., Vannier, G., Vernon, P. (2003): Is body size an influential parameter in determining the duration of survival at low temperatures in Alphitobius diaperinus (Panzer) (Coleoptera: Tenebrionidae). - Journal of Zoology 259: 381-388.

[43] Renault, D., Bouchereau, A., Delettre, Y. R., Hervant, F., Vernon, P. (2006): Changes in free amino acids in Alphitobius diaperinus (Coleoptera: Tenebrionidae) during thermal and food stress. - Comparative Biochemistry and Physiology-Part A: Molecular \& Integrative Physiology 143(3): 279-285.

[44] Rivers, D. B., Lee, R. E. L., Denlinger, D. L. (2000): Cold hardiness of the fly pupal parasitoid Nasonia vitripennis is enhanced by its host Sarcophaga crassipalpis. - Journal of Insect Physiology 46: 99-106.

[45] Ruberson, J. R., Kring, T. J., Elkassabany, N. (1998): Overwintering and the Diapause Syndrome of Predatory Heteropter. - In: Coll, M., Ruberson, J. R. (eds.) Proceedings, Symposium: Predatory Heteroptera: Their Ecology and Use in Biological Control. Annual Meeting of the Entomological Society of America, Indianapolis, IN, 1993. Thomas Say Publications in Entomology. Entomological Society of America, Lanham, MD, pp. 49-69. 
[46] Song, L. W., Tao, W. Q., Ling, L., Li, X. P., Chen, Y. Q. (2010): Influence of host plants and rearing density on growth, development and fecundity of Arma chinensis. - Scientia Silvae Sinicae 46: 105-110 (in Chinese).

[47] Storey, K. B., Storey, J. M. (1991): Biochemistry of Cryoprotectants. - In: Lee, R. E., Denlinger, D. L. (eds.) Insects at Low Temperature. Chapman and Hall, New York, pp. 64-93.

[48] Teets, N. M., Denlinger, D. L. (2013): Physiological mechanisms of seasonal and rapid cold-hardening in insects. - Physiological Entomology 38(2): 105-116.

[49] Teets, N. M., Denlinger, D. L. (2014): Surviving in a frozen desert: environmental stress physiology of terrestrial Antarctic arthropods. - Journal of Experimental Biology 217(1): 84-93.

[50] Thorpe, K. W., Aldrich, J. R. (2004): Conditions for short-term storage of field-collected spined soldier bug, Podisus maculiventris (Say) (Heteroptera: Pentatomidae), adults prior to augmentative release. - Journal of Entomological Science 39: 483-489.

[51] Tzanakakis, M. E., Veenendaal, R. L., Veerman, A. (1992): Effects of photoperiod and temperature on the termination of diapause in the univoltine seed wasp Eurytoma plotnikovi. - Physiological Entomology 17: 176-182.

[52] Wang, J., Guo, G. Q., Zhang, R. R., Dai, L. L., Chen, H. (2017): Metabolism and cold tolerance of Chinese white pine beetle Dendroctonus armandi (Coleoptera: Curculionidae: Scolytinae) during the overwintering period. - Agriculture and Forest Entomology 19(1): 10-22.

[53] Wang, W., Qin, L., Yan, J. H., Zhi, K., Lin, Z. Q., Zhang, X. H., Yang, Q. M., Wang, J., Ma, J., Sun, Y. L. (2012): Preliminary observation of preyed ability of Arma chinensis (Fallou), a new natural enemy of Hyphantria cunea (Drury). - Journal of Shandong Forestry Science and Technology 42(1): 11-14 (in Chinese).

[54] Worland, M. R. (2005): Factors that influence freezing in the sub-Antarctic springtail Tullbergia antarctica. - Journal of Insect Physiology 51: 881-894.

[55] Zou, D. Y., Wang, M. Q., Zhang, L. S., Zhang, Y., Zhang, X. J., Chen, H. Y. (2012): Taxonomic and bionomic notes on Arma chinensis (Fallou) (Hemiptera: Pentatomidae: Asopinae). - Zootaxa 3382: 41-52.

[56] Zou, D. Y., Coudron, T. A., Wu, H. H., Gu, X. S., Xu, W. H., Zhang, L. S., Chen, H. Y. (2015): Performance and cost comparisons for continuous rearing of Arma chinensis (Hemiptera: Pentatomidae: Asopinae) on a zoophytogenous artificial diet and a secondary prey. - Journal of Economic Entomology 108: 454-461. 